\title{
Kinetics and Mechanism Study of Oxidation of Diethylene glycol by Ditelluratoargentate (III) in Alkaline Media
}

\author{
Dan Wang, Chaochao Chen, Jinhuan Shan* \\ College of Chemistry and Environmental Science, Hebei University, Key Laboratory of Analytical \\ Science and Technology of Hebei Province, Baoding, 071002 Hebei, China
}

\begin{abstract}
The kinetics of oxidation of diethylene glycol by ditelluratoargentate (III) in alkaline medium has been studied by using spectrophotometer in the temperatures of $298.2 \mathrm{~K}-318.2 \mathrm{~K}$. All data was obtained in the pseudo-first order reaction. The reaction rate showed a first-order for [diethylene glycol]. The observed rates constants $\left(k_{o b s}\right)$ increased with increasing [reductant] and $\left[\mathrm{OH}^{-}\right]$, but $k_{\text {obs }}$ decreased with the increase of [Te ${ }_{4}^{2-}$ ]. In addition, there is a negative salt effect on the reaction of [diethylene glycol]. A plausible mechanism involving a slow reaction as the rate-controlled step is proposed and the rate equations derived from the mechanism can explain all the experimental results. Thus, the activation parameters at $298.2 \mathrm{~K}$ were calculated.
\end{abstract}

Keywords: ditelluratoargentate (III), diethylene glycol, Oxidation, Mechanism, Kinetics

\section{INTRODUCTION}

Since the early 20th century, people have found the presence of the highest oxidation state of transition metals, many scholars, at home and abroad, made the subject of study in different extent. The highest oxidation state of transition metals often chelated with other polydentate ligand to form a new substance, that is Transition metal chelate complexes, such as diperiodatoargentate (III) [1], ditellurat- oargentate (III) [2], ditelluratocurprate(III) [3] and diperiodatonickelate(IV) [4]. They are good oxidants in a medium with an approprate PH. This property that have high oxidability in appropriate condition, which provide a good oxidant for analysis, biology and life science research.

The pure natural mineral silver ion have recognized as one of the most safety, efficient, environmentally antibacterial material by the international. The valence of silver effect the bactericidal activity of it, the relative ability of sterilization of $\mathrm{Ag}$ (III) is high. The oxidation of some organic compounds and some in lower oxidation state metals by $\mathrm{Ag}$ (III) has been reported. Ag (III) complexes as an efficient disinfectant, can be used to disinfect the pool water. Ag (III) can oxidate some special biological molecules and drugs [5-7], this because Ag (III) complexes is very stable. Ditelluratoargentate (III) can used to oxidate some organic that have simple radical [8] and some lower valence metals [9]. But the reaction system is complex and the $\mathrm{Ag}$ (III) as the oxidation which in the highest valence, so if we want to understand the reaction, further research is needed, trying to make a reasonable explanation to the reaction mechanism.

Diethylene glycol is an important organic compound, In industry, it mainly used for dissolve some organic polymer compounds, such as nitrocellulose, rubber, resin, grease, paint, medicine and so on. In addition, it also can used for resin plasticizers, tobacco anti-dry agent, fiber lubricants and natural gas desiccant.

To understand more about the oxidation reaction by DTA and in order to explore the mechanism of oxidation by $\mathrm{Ag}$ (III) in alkaline medium, we have selected Diethylene glycol as a substrate for oxidation. This paper deals with the title reaction to investigate the redox chemistry of $\mathrm{Ag}$ (III) and to arrive at a plausible mechanism.

\section{EXPERIMENTAL}

\subsection{Material}

All chemicals used were of A.R. reagent grade. Doubly distilled water was prepared and used for all the solutions. The ditelluratoargentate (III) (DTA) crystals were synthesised [10] via oxidising Ag (I) in alkaline medium and modified by the reported method earlier [10]. Then the product detected by 
$\mathrm{UV} / \mathrm{vis}$ spectrum, and the absorption spectrum of ditelluratoargentate (III) complex showed an absorption maximum at $345 \mathrm{~nm}$. $\mathrm{KOH}$ and $\mathrm{KNO}_{3}$ were employed to maintain a state that the alkalinity and ionic strength in a steady in reaction solutions, respectively. The ditelluratoargentate (III) (DTA) must prepare again before using with double-distilled water.

\subsection{Methods}

kinetics measurements were performed under pseudo-first order conditions. The reaction contain two major substances, that is the ditelluratoargentate (III) serve as oxidizing agent and the alcohol serve as reductant, and in the ditelluratoargentate (III) added required quantities of $\mathrm{OH}^{-}, \mathrm{TeO}_{4}{ }^{2-}, \mathrm{KNO}_{3}$. The ionic strength was controlled by $\mathrm{KNO}_{3}$ solution and the $\mathrm{pH}$ was maintained by $\mathrm{KOH}$ solution. The ditelluratoargentate (III) and diethylene glycol were transferred separately to the upper and lower branch tubes of a $\lambda$-type two-cell reactor. Then blending the two reactant, put in a cuvette, detect with a UV-vis. The obtained absorption spectra of the ditelluratoargentate (III) well agree with the reported [10]. The first peak is observed at $345 \mathrm{~nm}$ and the second at $265 \mathrm{~nm}$ for the ditelluratoargentate (III), respectively. The concentration of ditelluratoargentate (III) has an absorption peak at $345 \mathrm{~nm}$.

The kinetic measurements were carried on a UV-vis. spectrophotometer (TU-1950, Beijing Puxi Inc., China), which had a cell holder kept at constant temperature $\left( \pm 0.1^{\circ} \mathrm{C}\right)$ by circulating water from a thermostat (DC-2006, Baoding, China). None of other species absorbed significantly at this wavelength.

\subsection{Product Analysis}

When the colour of ditelluratoargentate (III) completely fading that marked the reaction proceed completed. The main product of oxidation was identified as the corresponding aldehyde by its spot test [11].

\section{RESULTS AND DISCUSSION}

Under the conditions of [reductant $] 0 \gg[\mathrm{Ag}(\mathrm{III})] 0$, the plots of $\ln (\mathrm{At}-\mathrm{A} \infty)$ versus time were straight lines, showing that the reaction to DTA is first order, where At is the absorbance at time $t$ and $A \infty$ is at time infinite. The pseudo-first-order rate constants $\mathrm{k}_{\mathrm{obs}}$ were calculated by the method of leastsquares $(r \geq 0.999)$. The $k_{\text {obs }}$ values were caculated in an average method that on the basis of at least three parallel experiments, and reproducibility was within $\pm 5 \%$.

\subsection{The Effect of [reductant] on the Reaction Rates}

In the temperature range of $298.2 \mathrm{~K}-318.2 \mathrm{~K}$, The value of $[\mathrm{DTA}],\left[\mathrm{OH}^{-}\right],\left[\mathrm{TeO}_{4}{ }^{2-}\right]$ and $\mu$ remain constant, the [Diethylene alcohol] was varied from 0.01 to $0.05 \mathrm{~mol} \cdot \mathrm{L}-1$ at different temperatures. Methods the quantity effectiveness graph of [reductant] as abscissa, $\mathrm{k}_{\mathrm{obs}}$ as ordinate. The diagram shows $\mathrm{k}_{\mathrm{obs}}$ increased with the increase of reductant concentration and plots of $\mathrm{k}_{\mathrm{obs}}$ versus [reductant] were straight lines passing through the origin (Fig.1). In addition, according to the slopes of five plots that the plots is $\ln \mathrm{k}_{\mathrm{obs}}$ versus $\ln [$ reductant] showing that the reaction was first order.

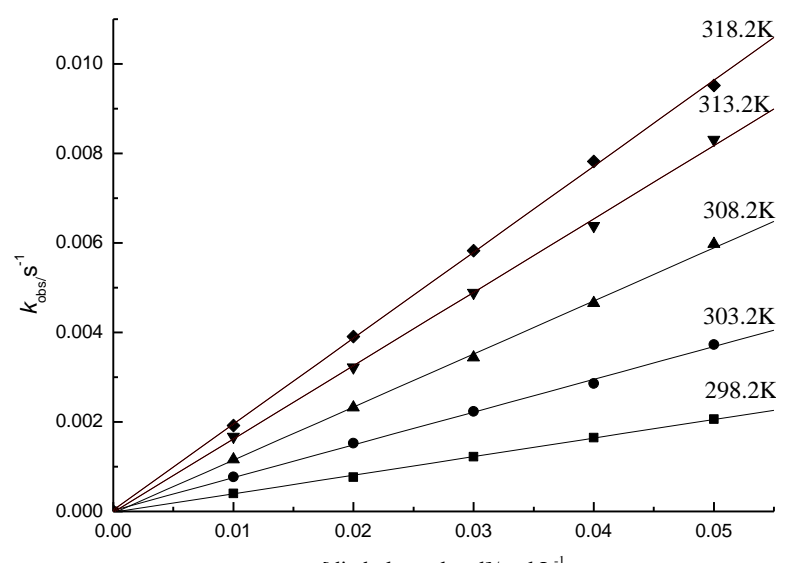

Fig1. Plots of $k_{\text {obs }}$ versus [diethylene glycol] at diffirent temperatures

$[D T A(I I I)]=3.61 \times 10-4 \mathrm{~mol} \cdot \mathrm{L}-1,\left[\mathrm{OH}^{-}\right]=1.00 \times 10-2 \mathrm{~mol} \cdot \bullet-1,\left[\mathrm{TeO}_{4}{ }^{2-}\right]=1.00 \times 10-3 \mathrm{~mol} \cdot \mathrm{L}-1, I=3.80 \times 10-2 \mathrm{~mol} \cdot \mathrm{L}-$ $1, r \geq 0.999$. 


\subsection{The Effect of [OH-] on the Reaction Rates}

At constant [DTA], [reductant], $\left[\mathrm{TeO}_{4}{ }^{2-}\right]$ and $\mu,\left[\mathrm{OH}^{-}\right]$was varied in the range of 5 to $25 \times 10-3 \mathrm{~mol} \cdot \mathrm{L}-$ 1. Methods the quantity effectiveness graph of $1 /[\mathrm{OH}]$ as abscissa, $1 / \mathrm{k}_{\mathrm{obs}}$ as ordinate. The plots of $1 / \mathrm{k}_{\mathrm{obs}}$ versus $1 /\left[\mathrm{OH}^{-}\right]$proved to be straight lines with a positive intercept, and the $\mathrm{k}_{\mathrm{obs}}$ increased with the increased of $\left[\mathrm{OH}^{-}\right]$in the temperature ranged from $298.2 \mathrm{~K}-318.2 \mathrm{~K}$.

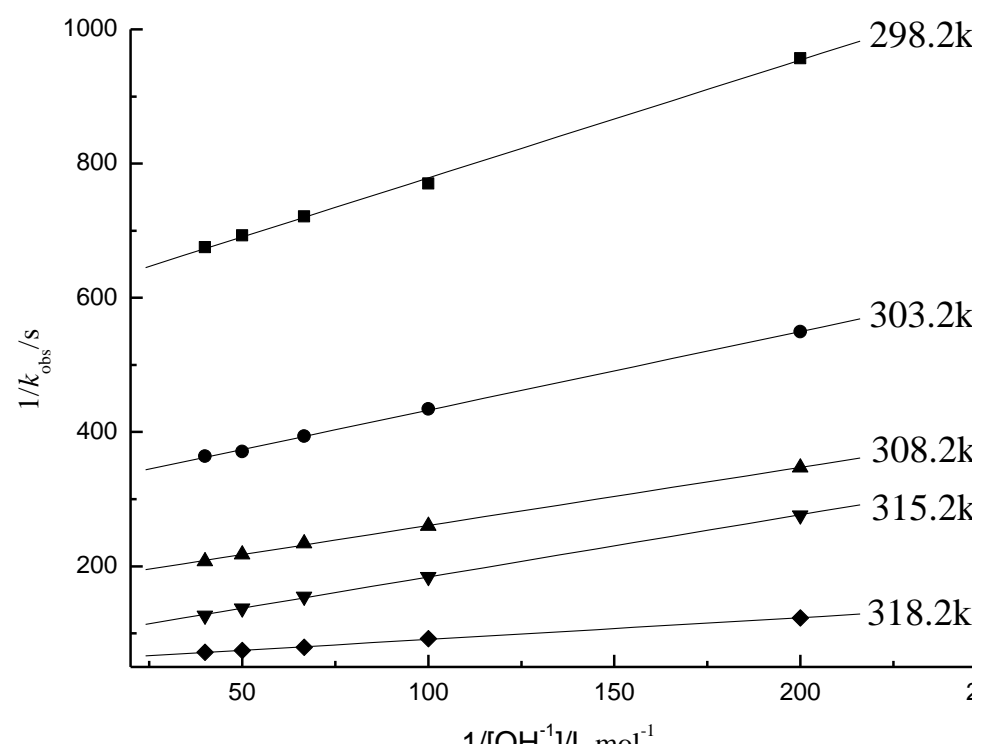

Fig2. Plots of $1 / k_{o b s}$ versus [OH-] at diffirent temperatures

$[D T A(I I I)]=3.61 \times 10-4 \mathrm{~mol} \cdot \mathrm{L}-1,[$ Diethylene $\mathrm{glycol}]=3.00 \times 10-2 \mathrm{~mol} \cdot \mathrm{L}-1$,

$\left[\mathrm{TeO}_{4}{ }^{2-}\right]=1.00 \times 10-3 \mathrm{~mol} \cdot \mathrm{L}-1, \mathrm{I}=3.80 \times 10-2 \mathrm{~mol} \cdot \mathrm{L}-1, r \geq 0.999$.

\subsection{The Effect of [TeO42-] on the Reaction Rates}

In the temperature range of $298.2 \mathrm{~K}-318.2 \mathrm{~K}$, make the value of [DTC], [OH${ }^{-}$, [reductant], and $\mu$ is certain, $\left[\mathrm{TeO}_{4}{ }^{2-}\right]$ was varied in the range of 0.50 to $2.50 \times 10-3 \mathrm{~mol} \cdot \mathrm{L}-1$. Methods the quantity effectiveness graph of $10\left[\mathrm{TeO}_{4}{ }^{2-}\right]$ as abscissa, $1 / \mathrm{k}_{\text {obs }}$ as ordinate. The plots of $1 / \mathrm{k}_{\text {obs }}$ versus $\left[\mathrm{TeO}_{4}{ }^{2-}\right]$ were straight lines with positive intercept . The experimental results showed that $\mathrm{k}_{\mathrm{obs}}$ decreased with increased of $\left[\mathrm{TeO}_{4}{ }^{2-}\right]$. So there is an inverse relationship between $\mathrm{k}_{\mathrm{obs}}$ and $\left[\mathrm{TeO}_{4}{ }^{2-}\right]$ (Fig. 3).

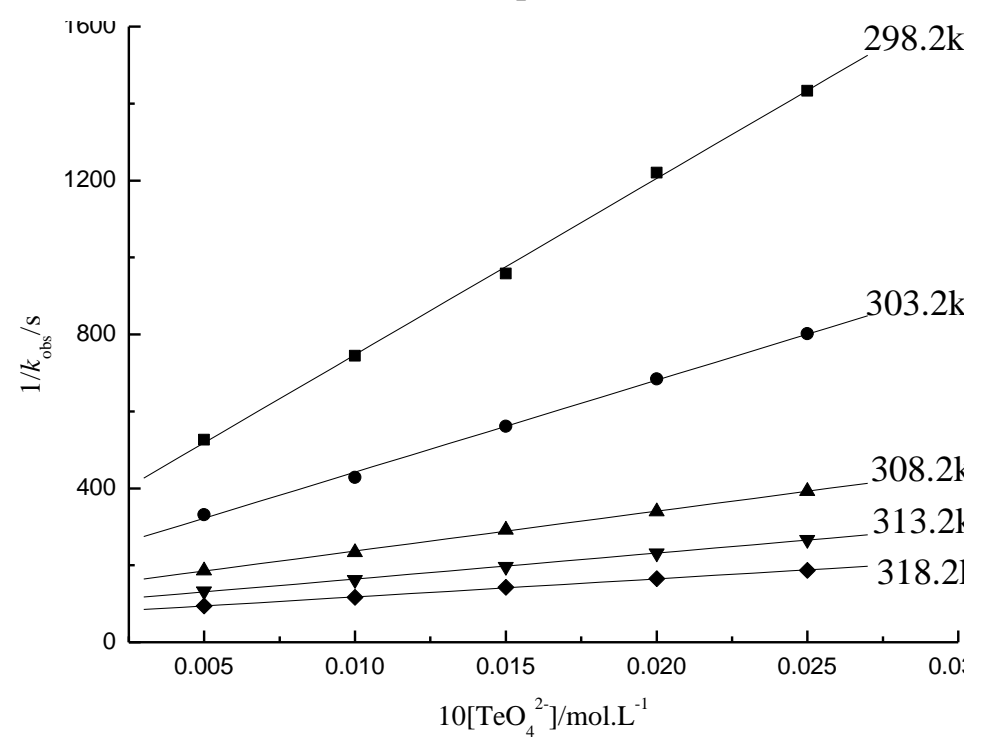

Fig3. Plots of $1 / k_{\text {obs }}$ versus $10\left[\mathrm{TeO}_{4}{ }^{2-}\right]$ at diffirent temperatures

$[D T A(I I I)]=3.61 \times 10-4 \mathrm{~mol} \cdot \mathrm{L}-1,[$ Diethylene $\mathrm{glycol}]=3.00 \times 10-2 \mathrm{~mol} \cdot \mathrm{L}-1$,

$\left[\mathrm{OH}^{-}\right]=1.00 \times 10-2 \mathrm{~mol} \cdot \mathrm{L}-1, \mathrm{I}=3.80 \times 10-2 \mathrm{~mol} \cdot \mathrm{L}-1, r \geq 0.999$. 


\subsection{The Effect of Ionic Strength on the Reaction Rates}

In $308.2 \mathrm{~K}$, make the concentration of [DTA], [reductant], $\left[\mathrm{OH}^{-}\right],\left[\mathrm{TeO}_{4}{ }^{2-}\right]$ at constant. The ionic strength was varied from 1.50 to $7.50 \times 10-2 \mathrm{~mol} \cdot \mathrm{L}-1$. It was found a negative salt effect in the oxidation of Diethylene glycol, thus indicating that $\mathrm{k}_{\mathrm{obs}}$ decreased with the ionic strength [12]

Table1. The diffirent $k_{o b s}$ in the 308.2K. [DTC $\left.(I I I)\right]=3.61 \times 10-4 \mathrm{~mol} \cdot \mathrm{L}-1$

$\left[\right.$ Diethylene glycol] $=3.00 \times 10-3 \mathrm{~mol} \cdot \mathrm{L}-1,\left[\mathrm{OH}^{-}\right]=1.00 \times 10-2 \mathrm{~mol} \cdot \mathrm{L}-1 .\left[\mathrm{TeO}_{4}{ }^{2-}\right]=1.00 \times 10-3 \mathrm{~mol} \cdot \mathrm{L}-1$

\begin{tabular}{|c|c|c|c|c|c|}
\hline$\mu \times 10^{2} / \mathrm{mol} \mathrm{L}^{-1}$ & 1.50 & 3.00 & 4.50 & 6.00 & 7.50 \\
\hline $10^{3} k_{\text {obs }} / \mathrm{s}^{-1}$ & 4.67 & 3.90 & 3.70 & 3.40 & 3.08 \\
\hline
\end{tabular}

\subsection{Reaction Mechanism}

In an alkaline medium, the electric dissociation equilibrium of telluric acid was given earlier [13] $(\mathrm{pKw}=14)$.

$$
\begin{array}{lll}
\mathrm{H}_{5} \mathrm{TeO}_{6}{ }^{-}+\mathrm{OH}^{-} \mathrm{C} \quad \mathrm{H}_{4} \mathrm{TeO}_{6}{ }^{2-}+\mathrm{H}_{2} \mathrm{O} & \lg \beta_{1}=3.049 \\
\mathrm{H}_{4} \mathrm{TeO}_{6}{ }^{2-}+\mathrm{OH}^{-} \mathrm{C} \quad \mathrm{H}_{3} \mathrm{TeO}_{6}{ }^{3-}+\mathrm{H}_{2} \mathrm{O} & \lg \beta_{2}=-1.00
\end{array}
$$

The distribution of all species of telluride in aqueous alkaline solution can be calculated from equations (1)-(2). In alkaline medium we assume that $\left[\mathrm{OH}^{-}\right]=1.00 \times 10-2 \mathrm{~mol} \cdot \mathrm{L}-1$, then $\left[\mathrm{H}_{4} \mathrm{TeO}_{6}{ }^{2-}\right]$ :[ $\left.\mathrm{H}_{5} \mathrm{TeO}_{6}\right]^{-}:\left[\mathrm{H}_{3} \mathrm{TeO}_{6}\right]^{3-}=1000: 89: 1$, so in the alkaline solution, the $\left[\mathrm{H}_{5} \mathrm{TeO}_{6}\right]^{-}$and $\left[\mathrm{H}_{3} \mathrm{TeO}_{6}\right]^{3-}$ species can be neglected, and the main species of telluride is $\mathrm{H}_{4} \mathrm{TeO}_{6}{ }^{2-}$. Based on such distribution and Rao argument [14], the formula of DTA may be represented by $\left[\mathrm{Ag}\left(\mathrm{H}_{4} \mathrm{TeO}_{6}\right)_{2}\right]^{-}$.

Based on the experimental results and discussion, the two plausible mechanisms were proposed as follows:

(R stands for Diethylene glycol)

$$
\begin{aligned}
& {\left[\mathrm{Ag}\left(\mathrm{H}_{4} \mathrm{TeO}_{6}\right)_{2}\right]^{-}+\mathrm{H}^{-} \stackrel{\mathrm{k}_{1}}{\mathrm{C}}\left[\mathrm{Ag}\left(\mathrm{H}_{3} \mathrm{TeO}_{6}\right)\right]+\mathrm{H}_{4} \mathrm{TeO}_{6}{ }^{2-}+\mathrm{H}_{2} \mathrm{O}} \\
& {\left[\mathrm{Ag}\left(\mathrm{H}_{3} \mathrm{TeO}_{6}\right)\right]+\text { reductant }-\underset{\text { slow }}{\longrightarrow} \mathrm{Ag}(\mathrm{I})+\text { Products }+\mathrm{H}_{4} \mathrm{TeO}_{6}{ }^{2-}}
\end{aligned}
$$

The reaction (4) was the rate-determining step, so the rate law of the reaction was derived as follows:

$$
-\mathrm{d}[\mathrm{Ag}(\mathrm{III})]_{\mathrm{t}} / \mathrm{dt}=k\left[\mathrm{Ag}\left(\mathrm{H}_{3} \mathrm{TeO}_{6}\right)\right][\text { reductant }]
$$

where $\mathrm{Ag}$ (III) $)_{\mathrm{t}}$ stands for any kind of which $\mathrm{Ag}^{3+}$ existing in equilibria (3) and (4), so $[\mathrm{Ag}(\mathrm{III})]_{\mathrm{t}}=\left[\mathrm{Ag}\left(\mathrm{H}_{4} \mathrm{TeO}_{6}\right)_{2}\right]^{-}+\left[\mathrm{Ag}\left(\mathrm{H}_{3} \mathrm{TeO}_{6}\right)\right]$

According to the equilibrium reaction (3)

$$
K_{1}=\frac{\left[\mathrm{H}_{4} \mathrm{TeO}_{6}{ }^{2-}\right]\left[\mathrm{Ag}_{\left.\left(\mathrm{H}_{3} \mathrm{TeO}_{6}\right)\right]}\right.}{\left[\mathrm{OH}^{-}\right]\left[\mathrm{Ag}\left(\mathrm{H}_{4} \mathrm{TeO}_{6}\right)_{2}\right]^{-}}
$$

Based of the equation (6) and (7), obtain

$$
\left[\mathrm{Ag}\left(\mathrm{H}_{3} \mathrm{TeO}_{6}\right)\right]=\frac{K_{1}\left[\mathrm{OH}^{-}\right][\mathrm{Ag}(\mathrm{III})]_{\mathrm{t}}}{K_{1}\left[\mathrm{OH}^{-}\right]+\left[\mathrm{H}_{4} \mathrm{TeO}_{6}{ }^{2-}\right]}
$$

Substituting the value of $\left[\mathrm{Ag}\left(\mathrm{H}_{3} \mathrm{TeO}_{6}\right)\right]$ into equation (5) we get equation

$$
\begin{aligned}
& -\mathrm{d}[\mathrm{Ag}(\mathrm{III})]_{\mathrm{t}} / \mathrm{dt}=\frac{k K_{1}[\mathrm{R}]\left[\mathrm{OH}^{-}\right]}{K_{1}\left[\mathrm{OH}^{-}\right]+\left[\mathrm{H}_{4} \mathrm{TeO}_{6}{ }^{2-}\right]}[\mathrm{Ag}(\mathrm{III})]_{\mathrm{t}}=k_{o b s}[\mathrm{Ag}(\mathrm{III})]_{\mathrm{t}} \\
& k_{o b s}=\frac{k K_{1}[\mathrm{R}]\left[\mathrm{OH}^{-}\right]}{K_{1}\left[\mathrm{OH}^{-}\right]+\left[\mathrm{H}_{4} \mathrm{TeO}_{6}{ }^{2-}\right]}
\end{aligned}
$$


Re-arranging equation (10) leads to equation (11)

$$
\frac{1}{k_{\text {obs }}}=\frac{1}{k[\mathrm{R}]}+\frac{\left[\mathrm{H}_{4} \mathrm{Te}_{\mathrm{e}}{ }^{2-}\right]}{k K_{1}[\mathrm{R}]} \frac{1}{\left[\mathrm{OH}^{-}\right]}
$$

From equation (9) can be know the reaction was first order for reductant or $\operatorname{Ag}\left(\right.$ III). The plots $k_{\text {obs }}$ versus [reductant] was straight lines passing through the origin at different temperatures. Equation (11) suggest that the plots of $1 / \mathrm{k}_{\mathrm{obs}}$ versus $1 /\left[\mathrm{OH}^{-}\right]$and $1 / \mathrm{k}_{\mathrm{obs}}$ vs $\left[\mathrm{H}_{4} \mathrm{TeO}_{6}{ }^{2-}\right]$ were also straight lines, in addition, $\mathrm{k}_{\mathrm{obs}}$ decreased with the increase of $\left[\mathrm{H}_{4} \mathrm{TeO}_{6}{ }^{2-}\right]$ and increased with the increase of $\left[\mathrm{OH}^{-}\right]$. Based on (11), according to intercept, the $\mathrm{k}_{\mathrm{obs}}$ can obtained, Using the transition-state theory, the activation energy and the thermodynamic parameters were evaluated at $298.2 \mathrm{~K}$ by the method given earlier [15] (Table2).

Table2. Rate constants of $k$ and thermodynamic activation parameters of the rate-controlling step

The plots of lnk versus 1/T have the following intercept (a), slope (b) and relative coefficient ( $r): a=20.82, b=-$ $6963.83, r=0.998$.

\begin{tabular}{|c|c|c|c|c|c|}
\hline $\mathrm{T}(\mathrm{K})$ & 298.2 & 303.2 & 308.2 & 313.2 & 318.2 \\
\hline$k \cdot 10^{2}\left(\mathrm{~mol}^{-1} \cdot \mathrm{L} \cdot \mathrm{s}^{-1}\right)$ & 11.51 & 16.45 & 25.01 & 34.35 & 47.02 \\
\hline $\begin{array}{l}\text { Thermodynamic activation } \\
\text { parameters }(298.2 \mathrm{~K})\end{array}$ & \multicolumn{5}{|r|}{$\mathrm{Ea} /\left(\mathrm{kJ} \cdot \mathrm{mol}^{-1}\right)=57.90, \Delta \mathrm{H}^{\ddagger} /\left(\mathrm{kJ} \cdot \mathrm{mol}^{-1}\right)=55.42}$, \\
$\Delta \mathrm{S}^{\mp} /\left(\mathrm{J} \cdot \mathrm{K}^{-1} \cdot \mathrm{mol}^{-1}\right)=-80.25$
\end{tabular}

\section{CONClusion}

Form the former discussed above the expermental, the rate constants and activation parameters for the reaction have draw. This reaction was assumed under pseudo-first order conditions, the experimental results showed that $\mathrm{k}_{\mathrm{obs}}$ decreased with increased of $\left[\mathrm{TeO}_{4}{ }^{2-}\right]$ and the $\mathrm{k}_{\mathrm{obs}}$ increased with the increased of $\left[\mathrm{OH}^{-}\right]$, this results consist with the mechanisms we discussed in the former. Through a equilibrium and a slow way reaction, the $\mathrm{Ag}$ (III) become $\mathrm{Ag}(\mathrm{I})$ by the removal of two electronics. In addition, there is an obvious negative salt effect in the oxidation of diethylene glycol, which because of the rate of the reaction markedly influenced by the migration rate of activated complex. The migration rate markedly decreases with the increase of the steric hindrance from the substituent of alcohol and the influence of space steric to it is obvious. The 'ion atmosphere' can be contain the effects between ions of the reaction and the migration rate of activated complex. So the rate of diethylene glycol affected by ionic strength is obviously and the $\mathrm{k}_{\mathrm{obs}}$ become lower because the exist of the 'ion atmosphere'. The mechanisms described are consistent with experiment results and kinetic results.

\section{REFERENCES}

[1] Shan J.H., Li S.M., Huo S.Y., Shen S.G., Sun H.W. Kinetics and Mechanism of the Oxidation of $\beta$-Alanine by Dihydroxydiperiodatoargentate(III) in an Alkaline Medium. Journal of the Iranian Chemical Society, 3 (2) (2005) 226-231

[2] Shan J.H., Yin C.H., Liu L., Liu Y.P. Kinetics and Mechanism of Oxidation of 1-Methoxy-2 propanol and 1-Ethoxy-2-propanol by Ditelluratoargentate(III) in Alkaline Medium. Asian Journal of Chemistry, 24 (11) (2012) 5225-5227

[3] Shan J.H., Wang Q.Q. Oxidation of Neopentyl glycol and 1,3-butanediol by Ditelluratocuprate (III) in Alkaline Medium. Oxid Commum, 38 (3) (2015) 1195-1203.

[4] Shan J.H., Shen H.X., Wang H.Y., Wang X.Q. Kinetics and Mechanism of L-lysine and Lornithine by Dihydroxydiperiodatonikelate(III) in Alkaline Liquids. Oxid Commum, 35 (3) (2012) 583-590

[5] Shen S.G., Shi H.M., Sun H.W. Oxidation of L-serine and L-threonine by Bis (hedrogenperiodato) argentite(III) Commplex anion: a mechanistic study. J Inorg Biochem, 101 (1) (2007) 165-172

[6] Shi H.M., Guo Y.K., Kang W.J. Kinetic study of the oxidation of N,N-Dimethylethanolamine by bis(hydrogenperiodato)argentite(III) in Aqueous Solution. Journal of Solution Chemistry, 40 (7) (2011) 1371-1381

[7] Shi H.M., Zhang J., Huo S.Y. Shi T.S. Kinetics and Mechanicsm of Oxidation of the Drug Intermediate 1-(2-Hydroxyethy) by Bis (hydrogenperperiodato)argentite III). Journal of the Brazilian Chemical Society, 24 (8) (2013) 1307-1313 
[8] Murthy C.P., Sethuram B., Rao Navaneeth T. Oxidation of aliphatic amines by ditelluratoargentate (III). Indian J Chem, 113 (8) (1982) 941-948

[9] Sridevi N., Rambabu R., Dikshitulu L.S.A. Kinetics and mechanism of oxidation of selenium (III) by ditelluratoargentate (III) [J]. J Indian Chem Soc, 69 (1992) 127-128

[10] Balikungeri A., Pelletier M., Monnie D. Contribution to the Study of the Complexes Bis(dihydrogentellurato)cuprate(III) and Argentate(III), Bis(hydrogenperiodato) cuprate(III) and Argentate(III). Inorg Chim Acta, 22 (1) (1977) 7-14

[11] Feigl F., Anger V. Spot Tests in Organic Analysis. Elsevier B.V. Publishing Co., New York, (1966) 41-161.

[12] Jin J.J. Kinetics Principle of Chemical Reaction in Liquid Phase. Science Technique Press, Shanghai, (1966) 186.

[13] Wang L.P. Shan J.H., Sun H.W. Existence of Transition Metals in Highest Oxidation State Complex. Journal of Hebei University (Natural Science Edition), 3 (24) (2004) 1000-1565

[14] Raviprasad T., Sethuram B., Rao T.N. Kinetics and mechanism of oxidation of lactic acid by dihydroxyditelluratoargentate (III) in alkaline medium. Indian Journal of Chemistry,18 (1979) 40-42

[15] Shan J.H., Han J., Y. LI, Zhang Z.W. The Oxidation of 2-(2-Methoxyethoxy)-ethanol and 2-(2Ethoxyethoxy)-ethanol by Ditelluratocuprate(III) in Alkaline Medium. Asian Journal of Chemistry, 26 (14) (2014) 4347-4350 